\title{
The Joy of Food Play \\ Gender and Class in Men's Auto/biographical Accounts of Everyday Food-ways
}

\author{
By Julie M. Parsons
}

\begin{abstract}
The Joy of Food Play - Gender and Class in Men's auto/biographical Accounts of Everyday Food-ways This article is informed by research that set out to investigate the relationship between individuals and their everyday food-ways using an auto/biographical research approach. The focus of this article centres on the notion of food 'play' rather than food 'work' as significant in the performance of a gendered cultural habitus, whereby men distanced themselves from notions of feminised domesticity and health discourses by resorting to both hegemonic masculinities and epicurean foodways. Despite a contemporary trend that emphasises fluidities across gender boundaries and shifting roles, the 75 respondents in the study that informs this article presented their food autobiographies as a type of transformation narrative heavily influenced by the continued intersectionalities of gender and class. Indeed, for the male respondents in this UK based study, a commitment to epicurean food-ways becomes a field for the performance of hegemonic masculinities with the gourmet food adventurer emerging from this culinary field coded elite and male. This raises questions with regards to cultural influences on everyday food-ways, as well as notions of what it means to be a gourmet, epicure, or food adventurer within a contemporary foodscape.
\end{abstract}

\section{KEYWORDS}

Gender, class, culture, food, gourmet, omnivore, epicurean, intersectionalities/ køn, klasse, kultur, mad, gourmet, omnivor, epikuroer, intersektionalitet

Dr Julie M. Parsons is the Sociology of Health and Illness Foundation (SHI) Mildred Blaxter Post-doctoral fellow for 2015-16. She is author of Gender, Class and Food, Families, Bodies and Health (2015) Palgrave MacMillan. Her research interests are in gender, class, culture, health, food and embodiment, as well as feminist, participatory and auto/biographical approaches to research. 


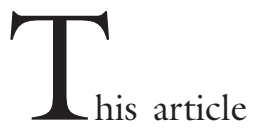

is informed by research that set out to investigate the relationship between individuals and their everyday food-ways using an auto/biographical research approach. I was especially looking for responses from men, as well as women and wanted the research to be liberated from the usual restrictions of time and space. I therefore used asynchronous online life-history interviews, which are part of a repertoire of computermediated communication (CMC), similar to correspondence techniques (Letherby and Zdrodowski 1995), in which respondents write on a particular theme. The use of CMC to gather data was a distinctive feature of this research. This culminated in a series of asynchronous online interviews with 75 self-selecting respondents (49 women and 26 men) over 9 months from the end of 2010 to 2011 , on the topic of food over the life course.

At the outset, I had anticipated gendered differences in approaches to everyday foodways, but not the extent to which these would be infused with cultural markers of class and status. The focus of this article is the male respondent's food narratives, particularly their use of hegemonic forms of masculinities (Connell 2005), such as "meat-eating, beer drinking and womanizing" (Gough, 2007: 237), as well as other 'masculine' attributes, such as pleasure and leisure, bravery, risk, adventure, economic success, knowledge, and expertise. The men in the study tended to emphasise how their everyday food-ways differed from a routinized, domestic femininity via reference to these types of cultural codes and values. In the following, I will demonstrate how these references were articulated in terms of a range of epicurean identities that draw upon a heady mix of hegemonic masculinities and culinary capital. The term epicurean is particularly useful as opposed to gastronomic, gourmet, foodie, or gour- mand, because it stresses the significance of the "sensual pleasure in good food and drink" (Waley-Cohen, 2017: 106). This is distinct from 'gastronomy' which is an "intimate understanding of the properties of food and a quest to achieve perfect balance" (Waley-Cohen, 2007: 104), that brings together 'pleasure and good health' (Drouard, 2007: 266). The men in this study were notably not concerned with health, dietary restraint or sustainability (Naccarato and Lebesco 2012).

Generally, all participants in the study presented their food auto/biographies by resorting to familiar codes associated with the intersectionalities of gender and class (Parsons 2015b). It is suggested that intersectionality is especially pertinent in discussions of identity, gender, and power (Davis 2008; Nash 2008; Ratna 2013), and whilst it is more often used with reference to the intersectionalities of gender and race $\left(\mathrm{Pu}^{-}\right.$ war 2004), it can also be useful for exploring other major/minor categories of gender intersections, such as (in no particular order) class, nation, (dis) ability, sexuality, age, religion, faith and migration. In considering the intersectionalities of gender and class in the field of everyday food-ways, it is notable that social, cultural, economic, and symbolic capitals (Bourdieu 1986) become gendered resources in boundary work and the demarcation of moral hierarchies.

There are therefore two interconnected purposes of this paper. First, to highlight how everyday food-ways continue to be infused with the intersectionalities of gender and class (culture) and, secondly, to explore how the 'gourmet food adventurer' emerges from the culinary field coded elite and male in contrast to the 'foodie' identified elsewhere (Cairns et al 2010; Johnston and Baumann 2010). The focus of this paper is specifically on 'epicurean' food-ways as a performance of elite cultural capital and 
hegemonic masculinities (Connell 2005). ${ }^{1}$ The corresponding 'emphasized femininities' expressed through everyday food-ways have been discussed elsewhere (Parsons $2014 a, 2014 b, 2015 a, 2015 b$ ). It is possible that these heavily gendered accounts might be a consequence of writing one's food story without the visible cues of gender; perhaps respondents had to work harder at presenting their food narratives as 'appropriately' male or female. However, these narratives provide a valuable insight into the contemporary milieu and anxieties about what counts as gender appropriate performances of everyday food-ways in a neo-liberal era of responsible individualism. Indeed, as Richardson (1997: 2) notes, we are "restrained and limited by the kinds of cultural stories available to us".

\section{BACKGROUND AND DeFINITIONS}

The term 'food-ways' usually refers to the production and distribution of food at a macro level. It is also used in anthropology when exploring food cultures or shared common beliefs, behaviours and practices relating to the production and consumption of food (Counihan 1999). In this paper, food-ways is also considered at a micro level, to reflect the multiplicity of ways of 'doing' food that incorporates all aspects of everyday food practices. This incorporates the notion of food-ways as an essential aspect of an individual's cultural habitus (Bourdieu 1984), which is cultivated and inculcated over time. Indeed, food-ways are narratives of relational affectation, or how we learn to know food, with our food preferences embedded, produced, and maintained through the practice of doing 'tastes', over and over again (Carolan 2011: $6)$. Thus food-ways are 'affective practices' (Wetherell, 2012: 96), because they are ongoing emotional, socially constructed, embodied, situated performances infused with sedimented social and personal history.

Further, food-ways has multiple mean- ings; it highlights the significance of modes of practice or ways of 'doing' food, as well as movement and direction across time (history) and space (culture). Consequently, food-ways connect the individual with the social through everyday practices (action/habit). The significance of food-ways or ways of doing food is reminiscent of West and Zimmerman's (1987) notion of 'doing' gender, Butler's (1999) conceptualisation of gender as performance, and Morgan's (1996) theories on "family practices" as significant in distinguishing between what families are and what families $d o$, in contrast to the institution of the family (Morgan 2011). A focus on food-ways therefore emphasises the embodied, affective, everyday food performances, and the interactions and temporal ways of doing food that connect past, present and future. It is notable therefore that food-ways (like gender and class) work within three interconnecting domains, (1) on an 'individual' level, through socialisation, internalisation, identity work, and the construction of the self, (2) through interactional cultural expectations and othering of practices and (3) via institutions that control access to resources, as well as ideologies and discourses (Risman 2004). Thus performances of everyday food-ways are validated, constrained and facilitated by reference to wider institutional contexts that may include gender (patriarchy), class (economics), culture (capital), and 'the' family (discourse). Accordingly, everyday food-ways inculcate a cultural habitus through the repetition, reproduction, and reinforcement of values and tastes.

It is notable that those engaged in epicurean food-ways can also be 'gourmets', defined as "a connoisseur of good food; a person with a discerning palette" (WaleyCohen, 2007: 104). This is therefore someone not necessarily engaged in cooking or preparing food, but able to recognise what counts as 'good food'. In a contemporary foodscape, this centres on the 
key domains of cultural omnivorousness, aesthetic appreciation (taste) authenticity (participation) and knowledge acquisition (Petersen and Kern 1996; Warde et al 2007). Moreover, Hollows (2003) argues that men engaged in domestic cookery do so as a creative leisure activity that distinguishes it from feminised domestic labour and as such it becomes "a domestic culinary masculinity" (Hollows, 2003: 239). Generally, men negotiated their identities, both within and beyond the domestic sphere, by recourse to a 'gourmet' identity that draws upon hegemonic masculinities alongside discourses of taste, participation, and knowledge of elite culinary capital (Naccarato and LeBesco 2012). Epicurean food-ways thus become significant for male identities because this stresses the importance of pleasure and food play, as opposed to the emphasised femininities identified with food work (family/maternal foodways) and the control of food (health/embodied food-ways). Indeed, again according to Brillat-Savarin [1825] "cuisine de ménage or domestic cooking; was woman's work, done every day in the home kitchen, [and] lacking prestige" (Drouard, 2007: 266).

\section{The STUdy}

The aim of the study was to examine the sameness and difference across 'our food stories' and how these 'stories' may have changed over the life course. The use of CMC enabled a far greater reach across the globe, albeit only to those with access to internet technology and an interest in food. Further, an auto/biographical approach was appropriate because it highlights the interconnectedness of the individual with the social, the autobiographical and biographical (Morgan 1998), the micro and the macro, the private and the public. This enables an exploration of the private troubles and public issues around everyday food-ways (Mills 1959), whilst demonstrat- ing the inter-textuality of auto/biographical accounts. These written texts were therefore social products, not unproblematic reflections of reality, but constrained by structural influences beyond their own free will (Stanley and Morgan 1993). I gained full ethical approval from the university hosting the study, and all respondents were given or chose their own pseudonyms. The focus of the inquiry was food over the life course, and respondents were invited to write their own autobiographical food narratives. Once they had agreed to participate I sent the following instructions:

What I'm really after is your 'food story'. Perhaps, this will include your earliest food memories, favourite foods, memorable food occasions, whether your eating habits have changed over time and why this may be. Also, absolutely anything food related that you'd like to share with me.

For some, if this proved difficult, I sent a series of questions along the same lines that centred on eating and cooking. I did not set out to question respondents specifically about 'healthy' food or eating, or a 'foodie' identity, it was very much open to them to tell their stories in their words and on their terms. This approach resulted in rich narratives and "thick descriptions" (Geertz 1973) that incorporated a range of food memories from the 1930s in the UK and beyond. The ages of the twenty-six male respondents ranges from 27 to 76, although they were mostly between the ages of 39 and 60. In terms of their NS-SES, eleven of the men identified themselves as belonging to social class 1 .

The most striking difference between these narratives and those from the women was the extent to which they were located within the public sphere and outward looking. In other words, their narratives were less to do with the domestic sphere, body management or the feminised practices of cooking as 'emotional' (Hochschild 1983; 
DeVault 1991) or 'love' 'labour' (Lynch 2007) and more to do with how their food and food-ways had led to the development of 'epicurean' (Scholliers 2001) or 'gourmet' or 'elite' (Bourdieu 1984) tastes, whether for 'fine-dining', 'good' food or cooking expertise. Indeed, respondents could mostly be considered 'gourmets' and/or 'food adventurers' (Heldke, 2003: xxiii) and used epicurean food-ways as markers of elite cultural capital, focusing on legitimate practices, knowledge acquisition, and cultural omnivorousness (Peterson and Kern 1996). Food shopping and cookery, rather than being highly feminised domestic activities, became part of a search for authentic or exotic cuisine and/or as an expression of expert knowledge, 'taste' and distinction (Johnston and Baumann 2010). These gourmet and epicurean identities assumed high levels of economic, social, and cultural capital and for the 'food adventurer' included elements of high adventure and risk.

After several levels of analysis running concurrently with data collection and beyond, five broad themes were identified and verified within the data. These were family, maternal, embodiment, health, and epicurean food-ways (Parsons 2015b). It is the last theme, which is the focus of this paper and considers both hegemonic masculinities and epicurean or gourmet identities. Significantly, epicurean food-ways continue to be associated with legitimate cultural capital and are coded as masculine. Notions of masculinity are thus connected to issues of taste, status, distinction, as well as notions of pleasure/leisure. It is the emphasis on food-ways as pleasurable that marks them as distinct from 'feminised' approaches to everyday food-ways (see Parsons 2014b, 2015b). These epicurean food-ways are therefore about asserting class status and a gender identity associated with hegemonic masculinities. Out of the twenty-six male respondents, some were obviously gourmets. Connor, Dave, Drew,
Ed, Fred, Gerry, Henry, James, Larry, Ralph, Simon, and Walt, for example, engaged in cultural omnivorousness, cooked and shopped for pleasure and leisure, and considered their cooking skills good if not 'restaurant standard'. The most committed of these were Dave, Drew, Ed, Gerry, Larry and Simon, who were also 'food adventurers'. There were others, such as Charlie, Ian, Nick, Paul, Quentin, Richard, Sam and Stephen who expressed a strong interest in 'fine-dining' and the sensual pleasures of food but did not cook much at all, mostly because their wives or partners were 'good' cooks or enjoyed cooking. These men could also be defined as epicures. Jake, Kevin, Lex, Mark, and Tom, on the other hand, were 'good' occasional cooks with more of a limited repertoire with preferences for cooking meat on the barbeque or open fire. Finally, Ollie had done "all the cooking for 3 or 4 years" when his "boys were babies" some 15 or so years earlier, but now claimed not to be 'passionate' about food, though he was a committed vegetarian. I cannot include narratives from all respondents but try to be as representative as possible and provide a table detailing all of the respondent demographics used in this paper (Dave, Drew, Ed, Fred, Gerry, Larry, Lex, Nick, Ollie, Sam, Tom, and Walt).

\section{EXPERTS AT PLAY IN a Culinary Field}

Surprisingly, all of the men - whether they might be considered gourmets, food adventurers or epicures and even those ostensibly not interested in food at all - resorted to a range of hegemonic masculinities and familiar cultural codes in their narratives. When considering the group that could be labelled 'gourmet' and 'food adventurers', it is clear that their narratives prioritized outside or 'foreign' influences, with epicurean tastes influenced by childhood experiences of living and travelling abroad. 
These external influences are significant and include references to school, University, work, as well as significant others who acted as mentors or tutors in the culinary arts. Gerry, for example, writes:

I was a very fussy child. I didn't really like things, which had much in the way of texture... Two good food memories of that time which I remember: firstly overcoming my aversion to the texture of mushrooms along with the young matron who gave me the nickname of Billy - which then stuck with me until I was 18 - we went mushroom picking in the big field next to school. Not magic mushrooms I should add - they came later!

It is notable that Gerry distances himself from the feminised associations with "fussiness" by reference to 'magic mushrooms'. Indeed, drug taking is the kind of risky activity that is usually coded as male and Robertson (2007: 47) argues that men are 'risk takers' and 'at risk' due to having to conform to notions of hegemonic masculinities. Hence, taking drugs is a kind of edgework and a means of "transcending the banality of every day existence" or "living on the edge as a means of performing dominant masculinity" (Collinson, 1996; Robertson, 2007: 48-9). Gerry continues his epicurean adventure and writes (emoticon and confidential comments in original text):

So - yes - college. Going to college meant having to "cook" for ourselves and/or live off takeaways - I think this phase really lasted ten years... There was also a short right-on phase of vegetarianism. AKA living off Bulgarian red wine, chips, bean stews and buckwheat bakes. This suited an agenda of direct-action, peace protesting activism. And the chips and red wine (and some speed too) suited parties, discos, club-nights in town, and occasional forays to London. The other food discovery of this time was hash-cakes:) (Assume this is confidential)... Then I moved to London to work on the [organization], and into a shared house where they ate bacon and sausages. My politics were already getting more flexible. My vegetarianism lasted about two weeks.

Here Gerry associates his vegetarianism with politics and the public sphere; it is not a domestic (feminised) concern. It is part of a lifestyle that incorporates more risky behaviour, such as drug taking and partying and activities usually associated with edgework (Collinson 1996). In Gerry's account this is also a phase and something he grows out of. This reinforces the association of femininity with vegetarianism and meat eating with masculinity that is well documented (Fiddes 1991; Adams 1990). Indeed, Bourdieu (2005: 75) argues that meat is "the nourishing food par excellence, strong and strong-making, giving vigour, blood and health". In Drew's narrative on becoming a gourmet he similarly writes:
Moved away from home at 19 - that's when cooking became a necessity, moving in with lads, cooking in was the cheapest option and the deal was if you cooked you did not clean up - so this I think was what swayed me. Moving to London opened my mind to a number of new ingredients; In- dian friends explained the herbs and that became my first endeavour into enjoying cooking. People liked my food, so I would cook more, and then it became expected, the boys would wait for me to come home to eat, even if I was home late.

Thus Drew positions himself as one of the lads (not feminine) and acquires additional status from his peers because of his cookery skills. Indeed, he was so good that the boys would wait for him to come home to taste his food. If men engage in other types of food work this was also contextualised by 
reference to hegemonic masculinities, for example Dave claims:

I proved to be a dab hand in the kitchen and was soon cooking the evening meal a couple of times a week. I not only enjoyed the preparation and cooking but also, much to the astonishment of male friends in the pub football team, the sourcing and buying of ingredients - food shopping in other words!

Hence, although food shopping is usually coded as highly feminised, Dave counters the potential contamination of this attribute by reference to "sourcing and buying ingredients", which implies expertise and skill. Indeed, he actually translates these activities for the reader, as "food shopping in other words". Further, whilst "it is feasible that shopping, cooking and enjoying a greater range of foods have been absorbed into current definitions of masculinity" (Gough, 2007: 328), Dave recounts this experience within the context of the pub and football, which are similarly coded masculine leisure pursuits and male coded spaces.

\section{Sensual Food Play}

For gourmet food adventurers such as Drew, cooking is not considered work at all, but represents a theatre for the performance and display of culinary expertise:

Cooking is relaxing to me - if I am cooking for family, small group or myself from my home kitchen... I always cook to the audience - nothing worse than food not being eaten, so if my parents are in town, I tone down the food, for Angus (friend) no seafood, kids then I like to have food they can play with dig into and enjoy.

Although Drew cares about the audience, this is not in the same sense as caring for the 'health' of the family or a need to dis- play appropriate family practices (Finch 2007). This is very much about the pleasure in pleasing others as a consequence of engaging in a personally fulfilling and relaxing leisure activity. Similarly, Dave notes "cooking continues to be a passion; it is my way of unwinding at the end of the working day". In Ed's narrative, his cooking is relaxed and exciting, not everyday, domestic cooking:

I enjoy cooking, but not to the extent that it is an ordeal and a worry. The whole buzz for me is serving up something that's tasty, and a good enough reason to get a bunch of my favourite people around the table.

So, for Ed, food is a social event and not a routinised everyday activity. Generally, for gourmets, food adventurers, and epicures, domestic, everyday cooking and shopping are not their primary concerns. Larry's response is typical, as he stresses how the "routine shopping is handled by my wife". He cooks only for special occasions:

[I cook] mostly for friends and family. I like to entertain and although Sunday roast is a favourite, I try to challenge myself from time to time... I have recently bought a new full width range/oven and it is definitely getting used.

It is notable that Larry refers to his recent purchase of a "full width range/oven"; this is a high status domestic item. Hence because cultural omnivorousness focuses on male activities and values outside of the domestic sphere, when gourmets bring their culinary practices into the home they are framed within different parameters that change the domestic space. Drew writes for example:

In doing up my first house in [Country] there was only one concern - I wanted to have a say in the kitchen design - the cooker etc. etc. - the rest of the house 
could be bright pink, I did not care as long as the kitchen looked good. Then the final move to a house with a big kitchen such bliss...

Drew is thus making his mark on the domestic space, it is his and not a feminine "bright pink" space. Indeed, Gough (2006: 387 ) argues that "cooking and enjoying diverse cuisine [are] no longer regarded as exclusively women's business", also that "it is feasible that shopping, cooking and enjoying a greater range of foods have been absorbed into current definitions of masculinity" (Gough, 2007: 328). Drew also writes about the acquisition of skills and knowledge as pleasurable:

My wife laughs about me sneaking off to the summerhouse with a bottle of wine and my "porn collection", which actually consists of one of my many, many, cookbooks - working out what to cook next and how to cook it...

Drew's reference to his cookery books as his "porn collection" is not "food porn" (which is something else), but a collection of books about cooking food. Instead of "sneaking off" to look at pornography, which is articulated as almost acceptable within the boundaries of heteronormative masculinity (his wife knows about it so it is acceptable) he is taking a bottle of wine with him (which adds to the sense of this being a sexual encounter) to his shed to read his cookery books. So, he cannot admit to reading about domestic cooking unless it is presented in terms of a highly sexualised, risky male arena.

\section{EPICUREAN Pleasures}

Some of the men who might be considered epicures on the other hand, while clearly interested in good food, did not, engage in cooking much at all. Nick, for example, writes that:
Sally is pretty much in charge of the kitchen so she plans what we eat really. When she's not around she tends to leave food / meal suggestions for me to do for the children. When I am here on my own I tend to revert to bachelordom... cereal, or toast or fried eggs. Don't really cook for me.

Thus, Nick is reaffirming the cultural norms that continue to divide domestic responsibilities in the home along gender lines. This is not a negotiated space, even when alone he does not admit to 'cooking' as his wife might cook. Instead, he acts like a single man; he is spontaneous, shows little regard for health discourses and throws together what is available and quick. However, he does take pleasure from food and continues:

We were also lucky enough to eat out in London quite a lot, linked to my Dad's work and his entertaining of overseas customers. I can remember eating in the Post Office tower-revolving restaurant and we had strawberries even though it was winter! I can also remember eating at Le Gavroche which even I realised was pretty special at the age of 11 or so... I absolutely love it. It is all part of the sensual experience of life, like music, paintings, sex etc.

Hence, Nick reinforces the connection between gender and class or culinary capital (Naccarato and LeBesco 2012), by identifying how they were 'lucky enough' to afford high status foods out of season (i.e. they were expensive). This highlights the notion of consuming prestigious foods as a deeply desirable experience associated with high cultural capital, art, and sex. Similarly, Sam writes that his wife makes decisions about their everyday food-ways, however he takes pleasure form cooking on an open fire. It is notable that for many men, cooking outside of the kitchen on an open fire or a barbeque liberates them from contami- 
nation from the feminising associations of cooking within a domestic sphere:

My wife Amelia generally decides what we are going to eat and this is governed by budget and time... I like to cook but seldom do and I love fresh ingredients... I am a great fan of fresh veg and my homemade hot chilli sauce is to die for. Nowadays I love to explore the tastes and textures of different foods and find myself very animated while cooking 'Potjiekos' on the fire. Potjiekos is a South African style of cooking in large cast iron pots over an open fire, very slow, all day stews, fabulous! As I have become more at one with food my cooking skills have got better and better, I still don't cook much but enjoy it when I do.

Indeed, it is notable that the BBQ and/or cooking on an open fire is considered a masculine domain. For example, Lex notes "I love BBQs" and Tom "when I decide to cook, I'm quite a good cook, but my repertoire is limited. They haven't changed much. Fry-ups and BBQs are my other specialties". This is also about choosing or deciding to cook, these are activities chosen for pleasure and enjoyment, they are not part of an enforced domestic responsibility or care work. Walt is a gourmet, who not only cooks on a BBQ but also claims that:

To share, to give to friends and family I use food, I love the art of food, as I love the gift of food, dinner parties, BBQs for 15 is normal for me, I enjoy the artistry of food, the planning, the balance, the mix, colour, tastes, variety of ingredients. I don't just do it for those who come, but for the pleasure of the creation.

This emphasises Walt's interest in the sensual pleasures of food, with the BBQ as an arena for demonstrating culinary skills and expertise, cooking in this way is art and performance. It is certainly not everyday domestic care work, but pure pleasure and a means of demonstrating his culinary intelligence and competence.

\section{Gourmet Globetrotting}

When documenting what influences his everyday food-ways, Ed writes: "eating Spanish style is what suits me. It's the whole experience and not just what's on the platter". Further, in terms of food experiences Fred reaffirms his gourmet globetrotting identity:

I love Thai and Japanese and Indian and that modern English vibe. I love sashimi. I don't really eat potatoes or much pasta (or indeed carbs). Totally favourite specific food items would be soft shell crab tempura, a rib of beef for two (the best one ever is sold at the Anchor \& Hope in Waterloo). I love almost all vegetables (especially raw). Some of the best food I've had at shacks (I remember salt cod fritters in Mexico and hawker food in Singapore). My two best restaurants in the world would be Gordon Ramsay, Hospital Road, Brompton and Tetsuya, Sydney, Australia. With both its as much about the experience as the exquisite food.

Indeed, experiences such as these add to the development of a specialised knowledge and understanding, which is significant in building a gourmet identity. According to food sociologists Johnston and Baumann, this gourmet identity includes "globetrotting, as finding new and exciting cuisines earns a kind of social status" (2010: 98100). Further, as noted earlier, gourmets have much in common with Heldke's (2003) "food adventurers". However, Heldke argues that "we like our exoticism somewhat familiar, recognizable, controllable" (2003: 19). Similarly, the globetrotting 'foodies' in Johnston and Baumann's study "avoided norm breaking exotic food". Indeed, they conclude that "the as- 
sumptions about foodies' interest in global cuisine is overstated and that whilst... norm breaking foods generated foodie cachet, most of the foodies... are generally not interested in adhering to that standard" (Johnston and Baumann 2010: 120-1). Yet, the gourmets in my study were interested in the exotic. Indeed, it is within the realm of eating offal that the test of a true gourmet or food adventurer comes in to play and this intersects with notions of "bravery" as a marker of hegemonic masculinity in the culinary field as Drew writes:

Talking of Beijing - let me share my favourite restaurant story - I was in Beijing with an Australian and American colleague. Having found a good local restaurant and persuaded them to eat there. We sat and perused the menu. Peking duck was a must and we selected some other dishes. Then I saw Devilled Duck Hearts as side dish and asked the waiter for a small bowl, as I was fascinated. They appeared small purple and plump covered in chilli oil and I started to eat them. I was asked by my colleagues what I was eating and advised - "duck hearts", "no you're not" was the response "they are olives" - "no they are duck hearts" I advised, although they did look like big olives. "Shut up and give me an olive" was the response. Handing the bowl over they carefully selected an 'olive' each.

And synchronised placed them in their mouths. Instant reaction, one swallowed and swore the other nearly threw up in a napkin. "They are duck hearts - why didn't you tell me" - this was probably the first time I have been reprimanded for telling the truth. Gladly I finished the bowl myself.

Indeed, according to Johnston and Baumann (2010: 120) "when food flagrantly violates social or culinary conventions, it creates a bold spectacle of norm breaking exoticism and this is especially evident in the foodie focus on eating offal". Hence, for the men in my study, these types of culinary adventures offer an ideal opportunity for performances of both culinary capital (Naccarato and LeBesco 2012) and hegemonic masculinities. Rule breaking and risk taking are traditionally associated with male cultural codes (Robertson 2007; Gough 2007), whilst a search for 'authentic' cuisine is a legitimate means of accruing cultural capital and social status within a contemporary foodscape. Overall, a gourmet identity is not coded as feminine and the gourmets are doing epicurean foodways by reference to masculine cultural codes. These are not family or maternal food-ways that centre on notions of obligation and responsibility. Indeed, gourmets are not preparing endless routinised meals for their families and they are not nurturing or feeding the family in De Vault's (1991) sense of the term. Instead, they demonstrate cultural omnivorousness, an appreciation of high and low cultural forms, in keeping with contemporary culinary capital, that emphasises aesthetic appreciation (taste), authenticity (participation), and knowledge acquisition (Johnston and Baumann 2010; Naccarato and LeBesco 2012). Throughout their narratives men highlight how they have built upon their knowledge, status, and expertise over time, and these are clearly discernable aspects of an epicurean identity.

\section{CONCLUSION}

In this paper I demonstrate how men in my study used everyday food-ways as a means of performing and/or displaying cultural capital and/or elite status. These epicurean food-ways were purely for leisure/pleasure (play) and not routinized chores (work). This includes food adventurers committed to epicurean food-ways, gourmets and epicures not interested in cooking but still engaged in fine-dining and the joy of eating/sharing good food.

What is notable is that these epicurean 
Table 1: Demographics of respondents who have been referred to in this paper.

$\begin{array}{llll}\text { No } & \text { Pseudonym } & \text { A } & \text { Occupation } \\ 52 & \text { Dave } & 59 & \text { Consultant } \\ 53 & \text { Drew } & 42 & \text { Senior Manager } \\ 54 & \text { Ed } & 55 & \text { Carpenter } \\ 55 & \text { Fred } & 39 & \text { Solicitor } \\ 56 & \text { Gerry } & 47 & \text { Solicitor } \\ 62 & \text { Larry } & 48 & \text { MD } \\ 63 & \text { Lex } & 42 & \text { MD } \\ 65 & \text { Nick } & 51 & \text { Consultant } \\ 66 & \text { Ollie } & 44 & \text { Teacher } \\ 71 & \text { Sam } & 50 & \text { Yachtsman } \\ 74 & \text { Tom } & 37 & \text { Occupational Therapist } \\ 75 & \text { Walt } & 57 & \text { Management }\end{array}$

$\begin{array}{ll}\text { Quals } & \text { Living Arrangements } \\ \text { GCSE* } & \text { Co-habiting } \\ \text { P/G } & \text { Married }+1 \text { child } \\ \text { GCSE* } & \text { Co-habiting }+1 \text { step-child } \\ \text { P/G } & \text { Single } \\ \text { P/G } & \text { Co-habiting } \\ \text { GCSE* } & \text { Married }+2 \text { children } \\ \text { GCSE* } & \text { Marries }+4 \text { children } \\ \text { Degree } & \text { Married }+2 \text { children } \\ \text { Degree } & \text { Married }+2 \text { children } \\ \text { Diploma } & \text { Married }+1 \text { child } \\ \text { Degree } & \text { Married }+1 \text { child } \\ \text { Diploma } & \text { Married }+3 \text { grown up children }\end{array}$

Key: $\quad A=$ Age

Quals $=$ Highest Qualification

$\mathrm{GCSE}^{*}=$ GCSE Equivalent

$\mathrm{P} / \mathrm{G}=$ Post-graduate qualification

identities were infused with forms of hegemonic masculinities, such as risk taking, bravery and adventure. This differentiates them markedly from foodies identified elsewhere (Baumann and Johnston 2010; Cairns et al 2010). At the same time, everyday epicurean food-ways were presented as recreational activities freely chosen and not part of a heteronormative feminised approach to food work, feeding the family (Devault 1991) or healthy family meals (Parsons 2014a, 2014b, 2015a). This would therefore indicate continuity in the gendered division of labour within the domestic foodscape, as health discourses in an obescogenic era have become more readily associated with women, who also remain the guardians of the family's health (Wills et al 2009). In my study therefore this particular blend of 'culinary capital' and hegemonic masculinities meant men were more likely to distance themselves from the cultural markers of culinary capital identified by Naccarato and LeBesco (2012) such as sustainability, health and dietary restraint, which could be coded as feminising concerns. Instead, the acquisition of culinary capital for men was more closely connected to sensual gratification related to food, success, and sex/sexuality. In this, the men in my study diverge from foodies identified in others because they did not express any interest in democracy, sustainability or health discourses. In addition, feeding the family was not a demonstration of appropriate care work (Johnston and Baumann 2010; Cairns et al 2010, Naccarato and Lebesco 2012) but an opportunity to demonstrate culinary skill and prowess. Thus I argue a gourmet identity continues to be coded masculine because it assumes high levels of economic, social, symbolic, and cultural capital that includes elements of high adventure and risk taking. Indeed, for male respondents in this UK based study, epicurean food-ways were infused with hegemonic masculinities, and this mix reworks Heldke's (2003: xxiii) "gourmet food adventurer". 


\section{Notes}

1. There were two women in the study who could be identified as 'gourmets' and it was notable that they charted a development of interest in epicurean food-ways due to relationships with men who were gourmets.

\section{ACKNOWLEDGEMENTS}

Many thanks to the anonymous reviewers and editors for their help and comments on earlier drafts of this paper.

\section{LITERATURE}

- Adams, Carol (1990): The Sexual Politics of Meat: A Feminist Vegetarian Critical Theory. Continuum, New York.

- Adkins, Lisa (2003): Reflexivity: Freedom or habit of gender?, in: Theory, Culture and Society 2016.

- Ashley, Bob, Hollows, Joanne, Jones, Steve and Taylor, Ben (2004): Food and Cultural Studies.

Routledge London.

- Beardsworth, Alan and Keil, Teresa (1997): Sociology on the Menu. An invitation to the study of food and society. Routledge, London.

- Beck, Ulrich (1992): Risk Society: Towards a New Modernity. Sage, London.

- Beck, Ulrich (2002): The Cosmopolitan Society and Its Enemies, in: Theory Culture Society,

19/1-2.

- Beck, Ulrich and Beck-Gernsheim, Erich (2002)

Individualization, Institutionalized Individualism and its Social and Political Consequences. Sage, London.

- Belasco, Warren (2008): Food, The Key Concepts. Berg, Oxford.

- Bourdieu, Pierre (1984): Distinction, A Social critique of the Judgement of Taste. Routledge, London.

- Bourdieu, Pierre (1986): The forms of capital, in Richardson, J. (ed.) Handbook of Theory and Research for the Sociology of Education. Greenwood, New York.

- Bourdieu, Pierre (2005): Taste of Luxury, Taste of Necessity, in: Korsmyer, C. (ed): The Taste Culture Reader: Experiencing Food and Drink. Berg, New York.
- Bradley, Harriet (2007): Gender. Polity Press, Cambridge.

- Brillat-Savarin, Jean A. (1970 [1825]): The Physiology of Taste. Penguin, London.

- Cairns, Kate, Johnston, Josée and Baumann, Shyon (2010): Caring about food: Doing Gender in the Foodie Kitchen, in: Gender and Society, $24 / 5$.

- Cairns, Kate, and Johnston, Josée (2015): Food and Femininity. Bloomsbury, London.

- Carolan, Michael (2011): Embodied Food Politics. Ashgate, Farnham.

- Charmaz, Kathy. (2006): Constructing Grounded Theory. Sage, London.

- Collinson, Michael (1996): In search of the high life: drugs, crime, masculinities and consumption, in: British Journal of Criminology, 36/3.

. Connell, Raewyn W. (2005) (2nd Ed): Masculinities. Polity Press, Cambridge.

- Counihan, Carol (1999): The Anthropology of Food and Body, Gender, Meaning and Power. Routledge, London.

- Davis, K. (2008): Intersectionality as buzzword: A sociology of science perspective on what make a feminist theory successful, in: Feminist Theory $9 / 1$. - Deleuze, Gilles, and Guattari, Felix (1998): A Thousand Plateaus. Athlone Press, London.

- DeSolier, Isabella (2013): Food and the Self: Consumption, Production and material Culture.

Bloomsbury Academic, London.

- DeVault, Majorie L. (1991): Feeding the Family. University of Chicago Press, London.

- Drouard, Alain. (2007): Chefs, Foodies and Gourmands, in Freeman, P. (eds.): Food: The History of Taste. Thames \& Hudson, London.

- Falk, Peter (1991): The Sweetness of forbidden fruit, towards an anthropology of taste, in Fürst, E.L. Prättälä, R. Ekström, M. Holm L. and Kjaernes, U. (eds.), in: Palatable Worlds: sociocultural food studies. Solum Forlag, Oslo.

- Fiddes, Nick. (1991): Meat A Natural Symbol. Routledge, London.

- Finch, Janet (2007): Displaying Families, in: Sociology $2007 / 41$ : 1 .

- Freeman, Peter (ed.) (2007): Food: The History of Taste. Thames \& Hudson, London.

- Geertz, Clifford. (1973): The Interpretation of Cultures. Perseus Books, New York.

- Giddens, Anthony (1991): Modernity and Self Identity, Self and Society in the Late Modern Age. Polity Press, Cambridge.

- Gough, Brendan (2007): Real Men don't diet: An analysis of contemporary newspaper representations of men, food and health', in: Social Science and Medicine 64/2. 
- Heldke, Lisa (2003): Exotic Appetites, ruminations of a food adventurer. Routledge, London. - Hochschild, Arlie R. (1983): The Managed Heart: Commercialization of Human Feeling. University of California Press, Berkeley.

- Hollows, Joanne (2003): Oliver's twist, leisure, labour and domestic masculinity in The Naked Chef, in: International Journal of Cultural Studies $6 / 2$.

- James, Trine Kjorholt, and Anne Tingstad,. (eds) (2009): Children, Food and Identity in Everyday

Life. Palgrave MacMillan, London.

- Johnston, Josée and Baumann, Shyon (2010):

Foodies, Democracy and Distinction in the Foodie

Kitchen. Routledge, London.

- Letherby, Gayle, and Zdrodowski, Dawn (1995):

"Dear researcher", the use of correspondence as a

Method within Feminist Qualitative Research, in:

Gender and Society $9 / 5$

- Lupton, Deborah (1996): Food, The Body and

The Self. Sage, London.

- Lupton, Deborah (2000): The heart of the meal: food preferences amongst rural Australian couples, in: Sociology of Health and Illness 22/1.

- Lupton, Deborah (2005): Lay Discourses and Beliefs related to food risks: An Australian Perspective, in: Sociology of Health and Illness, 27/4.

- Lynch, Kathleen (2007): Love labour as a distinct form of non-comodifiable form of labour care, in: The Sociological Review 2007/55:3.

- Marcus, George E. and Saka, Erkan (2006): Assemblage, in: Theory, Culture \& Society 23/2-3.

- Mills, Charles W. (1959): The Sociological Imagination. Penguin, London.

- Morgan, David (1998): Sociological Imaginations and imagining sociologiy: bodies, auto/biographies and other mysteries, in: Sociology 32/4.

- Morgan, David (2011): Rethinking Family Practices. Palgrave MacMillan, Basingstoke.

- Naccarato, Peter and LeBesco, Kathleen (2012), Culinary Capital. Berg, London.

- Nash, Jennifer C. (2008): Re-thinking Intersectionality, in: Feminist Review 89.

- Oakley, Ann (1992): Social Support and Motherhood. Blackwell, Oxford.

- Parsons, Julie M. (2014a): Cheese and chips out of styrofoam containers: An exploration of taste and cultural symbols of appropriate family foodways, in: A Journal of Media and Culture. - Parsons, Julie M. (2014b): When convenience is inconvenient, 'healthy' family foodways and the persistent intersectionalities of gender and class, in: Journal of Gender Studies.
. Parsons, Julie M. (2015a): "Good" Food as Family Medicine: Problems of Dualist and Absolutist Approaches to "Healthy" Family Foodways, in: Food Studies: An Interdisciplinary Journal.

- Parsons, Julie M. (2015b): Gender, Class \& Food; families, bodies and health. Palgrave MacMillan, Basingstoke.

- Peterson, Richard A. and Kern, Roger M. (1996): 'Changing Highbrow Taste: From Snob to Omnivore', in: American Sociological Review $61 / 5$

- Puwar, Nirmal (2004): Space Invaders: Race, Gender and Bodies Out of Place. Berg, Oxford, New York.

- Ratna, Aarti. (2013): Intersectional Plays of Identity: The Experiences of British Asian Female Footballers, in: Sociological Research Online, 18/1. - Richardson, Laurel (1997): Fields of Play, constructing an academic life. Rutgers University Press, New Brunswick, New Jersey.

- Risman, Barbara. J. (2004): Gender as social structure: Theory wrestling with activism, in: Gender and Society, 18/??.

- Robertson, Steve (2007): Understanding Men and Health, Maidenhead, OUP.

- Scholliers, Peter (ed.) (2001): Food, Drink and Identity, Cooking, Eating and Drinking in Europe since the Middle Ages. Berg, Oxford.

- Stanley, L. and Morgan, D. (1993): On Auto/

Biography in Sociology, in: Sociology, 27/1.

- Waley-Cohen, Joanna (2007): The Quest for Perfect Balance, in Freeman, P (ed.) Food: The

History of Taste. Thames \& Hudson, London. - Warde, Alan, Wright, D., and Gayo-Cal, M. (2007). Understanding Cultural Omnivorousness: Or the Myth of the Cultural Omnivore, in: Cultural Sociology $1 / 2$.

- Warde, Alan (2011): Cultural Hostility re-considered, in: Cultural Sociology 5/3 .

- West, Cadence and Zimmerman Don H. (1987):

Doing Gender, Gender and Society 1/2.

- Wetherell, Margaret (2012): Affect And Emotion, A New Social Science Understanding. London, Sage.

- Whitehead, Stephen (2002): Men and Masculinities. Polity, Cambridge.

- Wills, Wendy, Backett-Milburn, Kathryn, Lawton, Julia, Roberts Mei L. (2009): Consuming Fast Food: The Perceptions and Practices of Middle Class Teenagers, in: James, A., Kjorholt, T, Tingstad, V. (eds.) Children, Food and Identity in Everyday Life. Palgrave MacMillan, London. 